\title{
Identifying a Risk Profile for Thyroid Cancer
}

\begin{abstract}
The large use of simple and effective diagnostic tools has significantly contributed to the increase in diagnosis of thyroid cancer over the past years. However, there is compelling evidence that most micropapillary carcinomas have an indolent behavior and may never evolve into clinical cancers. Therefore, there is an urgent need for new tools able to predict which thyroid cancers will remain silent, and which thyroid cancers will present an aggressive behavior. There are a number of well-established clinical predictors of malignancy and recent studies have suggested that some of the patient's laboratory data and image methods may be useful. Molecular markers have also been increasingly tested and some of them appear to be very promising, such as BRAF, a few GST genes and p53 polymorphisms. In addition, modern tools, such as immunocytochemical markers, and the measure of the fractal nature of chromatin organization may increase the specificity of the pathological diagnosis of malignancy and help ascertain the prognosis. Guidelines designed to select nodules for further evaluation, as well as new methods aimed at distinguishing carcinomas of higher aggressiveness among the usually indolent thyroid tumors are an utmost necessity. (Arq Bras Endocrinol Metab 2007;51/5:713-722)
\end{abstract}

Keywords: Predisposition factors; Environment; Susceptibility genes; Outcome

\section{RESUMO}

Identificando um Perfil de Risco para Câncer de Tiróide.

O uso cada vez mais freqüente de métodos diagnósticos simples e efetivos tem contribuído significativamente para um aumento no diagnóstico de câncer da tiróide nos últimos anos. Entretanto, existem importantes evidências de que muitos dos microcarcinomas papilíferos têm um comportamento indolente e podem nunca evoluir para cânceres clínicos. Existe, portanto, uma necessidade urgente de desenvolver novas ferramentas capazes de predizer quais os tumores tiroidianos que permanecerão silenciosos e quais desenvolverão comportamento agressivo. Há uma série de marcadores clínicos de evolução bem estabelecidos e alguns estudos recentes sugerem que dados laboratoriais e métodos de imagem podem ser úteis. Marcadores moleculares também vêm sendo ativamente investigados e alguns, como BRAF, os genes GST e polimorfismos de p53, parecem promissores. Além disso, marcadores imunocitoquímicos e a medida da natureza fractal da cromatina podem aumentar a especificidade do diagnóstico anatomopatológico e ajudar a predizer o prognóstico. Existe uma necessidade imperiosa de elaborarmos diretrizes destinadas a selecionar os nódulos que merecem prosseguimento em sua avaliação, assim como novos métodos capazes de identificar lesões mais agressivas entre os geralmente indolentes tumores tiroidianos. (Arq Bras Endocrinol Metab 2007;51/5:713-722)

Descritores: Fatores de predisposição; Meio ambiente; Genes de susceptibilidade; Evolução

$\mathrm{R}$ ECENT IMPROVEMENTS IN MEDICAL technology have increased the detection of nodular thyroids, raising the incidence of incidental nodules to epidemic levels. Indeed, thyroid nodules may be detected in as much as $16 \%$ of imaging studies performed for other purposes on neck and chest computer revisão

\author{
LAURA Sterian WARD \\ ELAINE CRISTINA MORARI \\ JANAINA LUISA LEITE \\ NATASSIA ELENA BUfALO \\ ANA Carolina Trindade GUILHEN \\ Priscilla Pereira C. de Araujo \\ ALFIO J. TINCANI \\ LIGIA V.M. AsSUMPÇÃo \\ Patricia Sabino Matos
}

Molecular Genetics of Cancer Laboratory (LSW, ECM, JLL, NEB, ACTG \& PPCA) and Division of Endocrinology (LVMA) -

Department of Medicine, Head and Neck Surgery - Department of Surgery (AJT), and Division of Endocrinology - Department of Pathology (PSM), Medical Science School, State University of Campinas - Unicamp, Campinas, SP.

Recebido em 22/02/07

Aceito em 14/04/07 
tomography scans, magnetic resonance, carotid Doppler studies and, especially, ultrasonography (1). The physician, encountering one of these lesions, is faced with a dilemma on which is the best course of management of this incidental finding (2). Fine-needle cytology has been more frequently indicated in view of the anxiety of most patients and the lack of reliable parameters of malignancy, this is certainly one of the causes of the increase in thyroid cancer detection we have been observing over the past decades (3). Aggressive evaluation of nodular thyroids has consequently contributed to a sharp increase in the number of small papillary carcinomas operated (3). However, there is compelling evidence that most of these tumors would never evolve clinically.

\section{THYROID CANCER BIOLOGY}

Microcarcinomas, defined by the World Health Organization as carcinomas $1.0 \mathrm{~cm}$ or less in diameter, have been described in $1 \%$ to $35.6 \%$ of autopsy studies and $5.5 \%$ to $10.5 \%$ of thyroid glands removed due to causes other than malignancy (4-11). Considering that thyroid cancer incidence in Brazil, as in most countries, presents in no more than $0.3 \%$ of men and $1 \%$ of women, a great part of microcarcinomas detected by ultrasonography in autopsies or surgical specimens will probably never evolve into clinical cancers $(3,12)$. Searching for indicators of the clinical evolution of papillary microcarcinomas, we studied a total of 32 lesions identified during autopsy and in surgical specimen material. These lesions were found in $7.8 \%$ of the 166 consecutive autopsies examined and $7.2 \%$ of 261 thyroids that were surgically removed due to thyroid diseases in general, with a higher incidence between the ages of 30 and 49 years (13). Both genders were similarly affected: $9.3 \%$ of men and $8.8 \%$ of women in autopsy series, and $6.2 \%$ of men and $7.3 \%$ of women in surgical series, suggesting that hormonal factors may favor the subsequent development of clinical lesions in women (14). Indeed, the higher incidence of thyroid carcinoma in women during reproductive years compared to men, and the increased risk associated with the therapeutic use of estrogens have suggested a pathogenetic role exerted by these steroids in the development of thyroid cancer (14). In addition, gender is a significant prognostic marker, since women with differentiated thyroid carcinomas show a better survival than men in our own data and that of others $(15,16)$. Recent studies have provided a new insight into the molecular mechanisms through which estrogens may induce the progression of thyroid cancer, demonstrating that the G protein-coupled receptor 30 (GPR30) and the mitogen-activated protein kinase (MAPK) pathway mediate both the upregulation of $\mathrm{c}$-fos and the growth response to $17 \beta$-estradiol (E2), genistein (G), and 4-hydroxyta-moxifen (OHT) in thyroid cancer cell cultures (17).

In addition to estrogens, other factors may certainly take part in the thyroid cancer pathogenetic process. It is reasonable to think that risk factors of thyroid cancer may also define tumor behavior and, in consequence, their outcome. The American Joint Committee on Cancer and International Union Against Cancer, together with the National Comprehensive Network (AJCC/UICC and NCCN), summarized the risk factors for metastases, recurrence and fatal outcome, taking into account patient and tumor data, as demonstrated in table 1 (18).

Unfortunately, most prognostic factors depend on tumor examination, preventing any other action before surgical intervention. Prognostic classification and risk group stratification have improved during the last two decades with a deeper understanding of the biology of well-differentiated thyroid tumors. However, level 1 evidence is not yet available, there are no prospective randomized trials based on a variety of treatments, mainly total versus less than total thyroidectomy and surgery versus observation for papillary microcarcinomas. Decisions on thyroid cancer management are based mainly on retrospective studies used to define staging systems. The most common

Table 1. Prognostic factors for metastasis, recurrence and death risk from differentiated thyroid carcinomas (18).

\begin{tabular}{ll}
\hline Patients & Tumor \\
Age $<15$ years or age $>45$ years & Tumor: large $(>2 \mathrm{~cm})$ \\
Male gender & Localization: multifocal, bilateral \\
History of familial thyroid cancer & Local tumor invasion: beyond the capsule \\
& Subtypes: tall, columnar and Hürthle cell \\
& Nuclear atypia and tumor necrosis: accentuated \\
& Vascular invasion: present \\
& Cervical or mediastinal lymph nodes \\
& Distant metastases \\
& Low or no iodide uptake by the tumor and/or the metastases \\
\hline
\end{tabular}


staging system, TNM (tumor, node, metastasis), which adheres to the biology of tumors, has been extensively reviewed over the years (19), and has been successfully used for over 65 years in thyroid cancer patients (20). However, the literature still lacks an analysis of the TNM and other scoring systems (OSU, ACES, AMES, etc.), as well as accuracy and utility concerning papillary microcarcinomas. Our data indicated that extrathyroidal extension and lymph node metastases, which are important TNM elements, do not correlate with outcomes of patients with papillary microcarcinomas (21). In a cohort of 68 patients with papillary microcarcinomas followed-up for 103 months (15 to 289 months), we observed no deaths but a relatively high number (19.1\% of the cases) of unfavorable events, such as local recurrence and even long-distance metastasis (21). These patients responded well to the therapeutic measures: $50 \%$ of TNM III or IV PMC patients remained free of disease during the follow-up. Therefore, TNM alone was not able to predict favorable or unfavorable outcome of these patients, as demonstrated in figure 1.

In addition, the independent value for each parameter needs to be determined in a multivariate analysis of all risk factors for each individual patient (22). Moreover, the influence of good number risk factors for differentiated thyroid cancer on the prognostics of these tumors has not been investigated. A population-based nested case-control study of the 5,554 differentiated thyroid cancer patients diagnosed in Sweden from 1958 to 1978 investigated the cause of death of thyroid cancer patients matched by age at diagnosis, gender, and period calendar controls (23). The authors aimed to investigate how factors such as smoking, number of children, previous thyroid disorders, previous radiotherapy toward the neck, family history of thyroid diseases

\section{PTC}

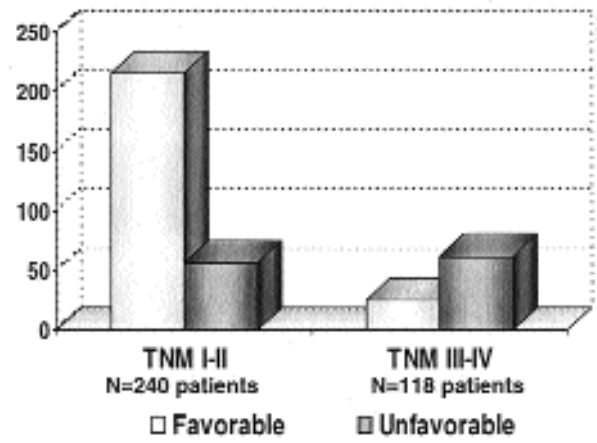

and malignancies influenced survival. The analysis of the 595 cases and controls showed that smokers had a borderline significant increased risk of dying from differentiated thyroid cancer. Previous radiotherapy towards the neck region had no prognostic implication. A family history of differentiated thyroid cancer influenced prognostics although not significantly in a few cases (23). The remaining risk factors studied did not influence survival. The authors concluded that smokers appeared to have a worse prognostic compared to nonsmokers, and a family history of thyroid cancer had a non-significant negative effect on survival (23). Our data on micropapillary carcinomas showed a similar trend (13). Although associated nodular goiter was observed in $54 \%$ of autopsies and 26\% of surgical specimens, and Hashimoto's thyroiditis was observed only in surgical material (15\% of the cases), we were not able to correlate risk of malignancy with any concomitant lesion and we could not find risk factors for clinical evolution evaluation (13). However, we observed that the smallest papillary microcarcinomas appeared most frequently as nonencapsulated nonsclerosing tumors without inflammatory infiltrate or fibrosis, suggesting that they could represent the early stages of development thereby raising questions concerning the role of the immune system in delaying the progression of these tumors (13). There is evidence that oncogene-induced cytokine secretion is important for the development and progression of thyroid carcinomas in genetically permissive hosts (24). We demonstrated earlier that the odds for patients with a previous history of thyroid autoimmune disease $(\mathrm{p}<0.02)$ or with thyroid autoantibodies $(\mathrm{p}<0.001)$ having a worse outcome were lower than for patients with no evidence of autoimmune activity, suggesting that autoimmune activity against the gland may exert a protective effect on the outcome of patients with differentiated thyroid

\section{PMC}

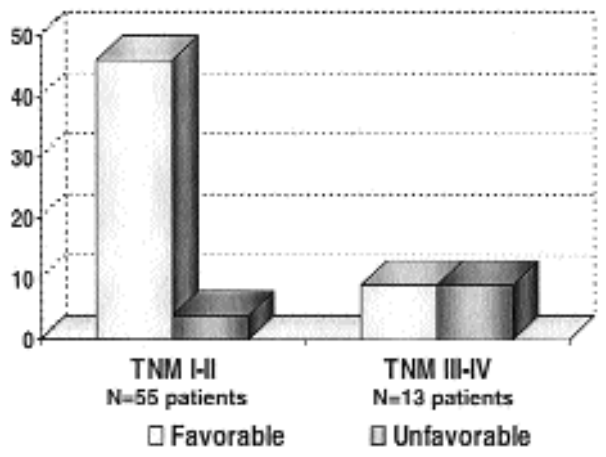

Figure 1. Graphical comparison between TNM classification system and outcomes, defined as favorable or unfavorable, in 68 papillary thyroid microcarcinomas with less than $1 \mathrm{~cm}$ in diameter (PMC), and in 358 papillary thyroid carcinomas larger than $1 \mathrm{~cm}$ (PTC non-PMC). 
carcinoma (25). Markers of immune activation against the neoplastic tissue may be useful.

The literature is quite intriguing regarding the influence of smoking habits on thyroid cancer. Many epidemiologic observations were not able to associate cigarette smoking with thyroid cancer and some even found a lower risk for thyroid cancer among smokers. Twelve out of 13 case-control studies that examined the association between cigarette smoking and thyroid cancer found the risk of thyroid cancer to be decreased by $40 \%$ among smokers (26). Cohort studies, including a prospective Canadian one, were unable to demonstrate any association between smoking history and the risk of thyroid cancer (27). In addition, we were not able to find any correlation between smoking, clinical features, parameters of aggressiveness at diagnosis or during follow-up of 248 patients with thyroid nodules, including 67 benign goiters, 13 follicular adenomas, 136 papillary carcinomas and 32 follicular carcinomas, and 277 controls with similar ethnic backgrounds (28). Why would smoke influence the outcome of thyroid cancer patients in the Swedish study (23)? It is possible that other effects of the many toxic compounds existing in cigarette smoke, on other organs or systems, besides the thyroid, were responsible for this influence. Nevertheless, the role of smoke on thyroid cancer outcome remains to be elucidated. Likewise, the influence of the genetic profile and environmental factors on thyroid cancer biology remains largely unknown.

It has been proposed that incidental cancer found by histological examination of goiters would hold lower potential aggressiveness than cancers detected by fine-needle aspiration considering prognostic features, such as multifocality, lymph node metastasis and extracapsular invasion (29). On the other hand, there are many reports on the aggressive behavior of papillary microcarcinomas, which evolve not only with lymphatic regional metastases, but also with blood-borne lung, bone and brain metastases $(30,31)$.

What do you know about differentiated thyroid cancer and how can you use this knowledge in order to define susceptibility profile and outcome for differentiated thyroid cancer?

\section{ENVIRONMENTAL AND GENETIC RISK FACTORS FOR DIFFERENTIATED THYROID CARCINOMAS}

Thyroid cancer is the most frequent endocrine cancer with a geographic variation in its incidence and manifestations (32). While it does not account for more than $1 \%$ of all human cancers in most countries, in other regions such as the Middle East, thyroid cancer is the second most common neoplasm among women (33). Brazilian data also show a highly distinctive incidence of thyroid tumors in different regions of the country (12). This great variation in incidence reflects differences not only in the access to health care and possibly diverse methods or thoroughness of thyroid examination, but also in environmental and genetic characteristics of the populations studied.

Exposure to ionizing radiation, especially during childhood, remains the only factor clearly associated with benign and malignant thyroid tumors in humans (34), although there is strong epidemiological evidence pointing towards the involvement of geographic, ethnic and dietary factors in the risk of sporadic thyroid cancer $(32,34,35)$.

The most relevant genetic alterations identified so far in the different progression stages of thyroid tumors include $R A S$ mutations in follicular tumors (36), RET gene rearrangements and $B R A F$ mutations in papillary carcinomas $(37,38), P P A R \gamma$ $P A X 8$ mutations in follicular carcinomas (39), and p53 mutations in poorly differentiated and anaplastic carcinoma (40). There is compelling epidemiologic, experimental and clinical evidences that exposure to ionizing radiation may trigger a series of abnormalities related to these genes' activation or inactivation, aside from producing genetic instability (41). A lowlevel genomic instability may even be a feature of papillary thyroid carcinoma (42). However, we still do not understand why some individuals exposed to ionizing radiation develop thyroid cancer whereas others do not. The age at exposure has been shown to be a critical risk factor for developing thyroid carcinoma after exposure to fallout from Chernobyl, with those under the age of 1 showing a much greater risk than older children. There is a rapid decline to a level of relatively low risk for young adults $(43,44)$. A similar situation was portrayed in Nagasaki and Hiroshima, where atomic bomb survivors displayed one of the highest solid tumor risk estimates (45). The likely reasons for this age-related risk include iodine radioisotope intake, radioiodine uptake, and biological sensitivity factors. The existence of biological sensitivity factors is confirmed by the finding of a similar, although less marked agerelated, sensitivity to thyroid carcinomas after exposure to external radiation (46). Two main reasons for this sensitivity could be either the mitotic rate at the time of radiation exposure or the number of mitoses that occur in the progeny of the mutated cell, or perhaps both (47). 
What other environmental factors may also contribute to the increasing incidence of cancer, not only in regions affected by fallout but in other countries as well?

Iodine has long been recognized as an important factor in thyroid cancer pathogenesis. Iodine-deficient thyroid glands will of course show a high radioactive iodine uptake, leading to the prediction that risk of developing thyroid carcinoma after exposure to radiation would be greater in areas with greater iodine deficiency. In fact, the type and consequent aggressiveness of thyroid tumors seem to be related to the population's iodine intake, although a clear relationship between iodine supply to the population and sporadic thyroid cancer incidence, as well as its alleged physiopathology are still unclear (48). This issue is discussed by Nobel and Medeiros-Neto in another article of this same journal.

Some of the genes related to thyroid carcinogenesis have been related to tumor aggressiveness and, hence, to prognostics. Many studies, using both immunocytochemical and genetic analyses, have shown that $p 53$ mutations are highly prevalent in poorly differentiated and undifferentiated thyroid carcinomas, as well as in thyroid cancer cell lines $(40,49)$. However, these mutations are not found in benign tumors and are infrequent in well-differentiated cancers, suggesting that mutational inactivation of $p 53$ occurs at a late stage of thyroid tumor progression and may represent a key event in the progression from differentiated to anaplastic carcinomas $(50,51)$. Preliminary data of our group using immunohistochemistry for p53 in 34 papillary carcinomas, including 21 cases

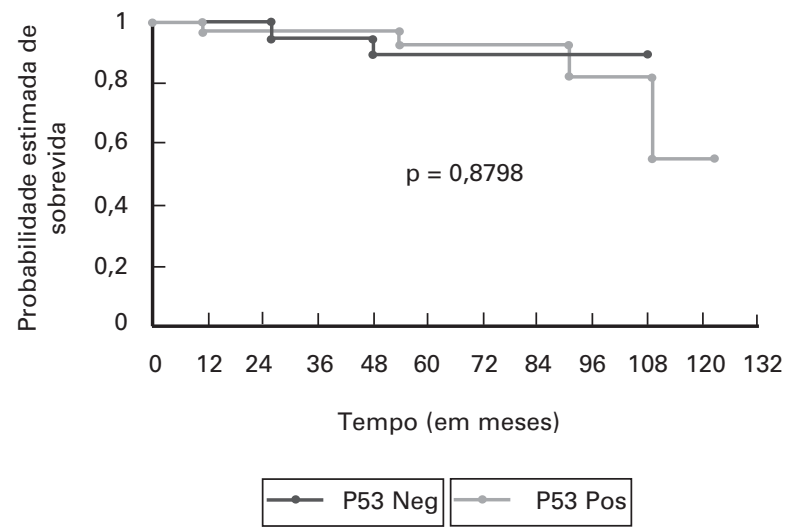

Figure 2. Kaplan-Meier survival curve (estimated probability of survival) of 50 differentiated thyroid cancer patients that were either immunohistochemically p53 positive or negative followed-up for 120 months. of the classical histological type, 7 tall cell variants and 6 of the follicular variant type; 16 follicular carcinomas; 4 medullary and 3 anaplastic carcinomas did not confirm a relationship between the expression of p53 and prognostics. However, the Kaplan-Meier survival curve of these patients, displayed in figure 2, suggests that a longer follow-up and/or a larger cohort may prove p53 to be a reliable immunohistochemical, and perhaps even a immunocytochemical, prognostic marker. Furthermore, we tested the gene $M U C$, which was described as overexpressed in aggressive thyroid carcinomas (52). MUCl overexpression is a key molecular event in the pathogenesis of aggressive thyroid tumors (53). In malignancy, MUCl looses its polarized expression, redistributes, and is expressed on the whole cell surface. This redistribution shields other cell surface molecules from their ligands and interferes with integrin-mediated adhesion to the extracellular matrix and with cadherin-mediated cell-cell adhesion. Increased MUCl expression thereby promotes cellular dissociation and oncogenic progression (53). MUCl upregulation also protects tumor cells from immune recognition and destruction by the cellular arm of the immune system. Moreover, it has been shown to inhibit human T-cell proliferation, thereby contributing to cancer-propagated immunosuppression (53). Previous studies from Wreesmann et al. identified MUCl expression in thyroid slides (52). We were able to reproduce this technique, but in the 50 differentiated thyroid tumors studied in a preliminary protocol, we were not able to associate MUC expression with the patients' outcome (figure 3 ).

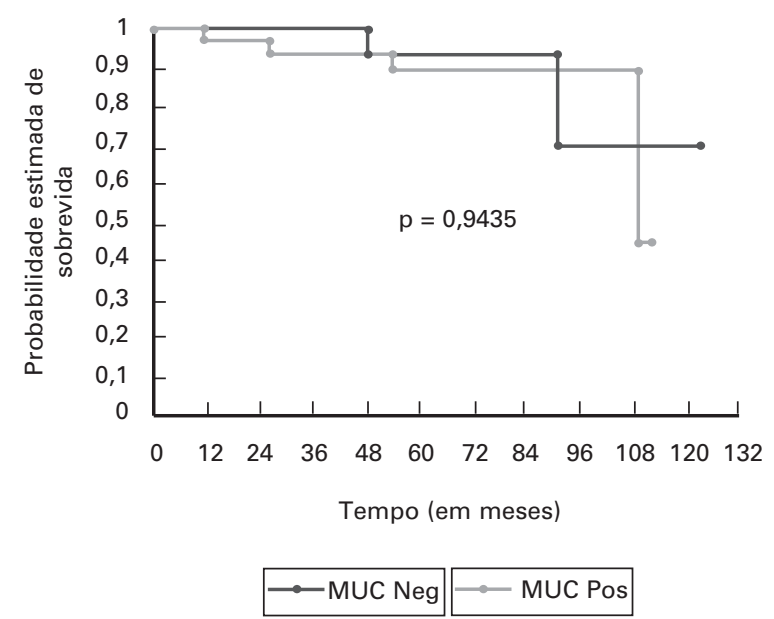

Figure 3. Kaplan-Meier survival curve (estimated probability of survival) of 50 differentiated thyroid cancer patients that were either immunohistochemically MUC positive or negative followed-up for 120 months. 
We also investigated a gene that encodes a key protein for thyroid cancer detection and treatment and therefore related to patients' outcome: NIS. The sodium iodide symporter (NIS) protein expression and functional integrity is essential to assure a radioiodine uptake high enough to detect and destroy any tumoral thyroid tissue. The absence of radioiodide uptake is associated with high recurrence rate and reduced survival (54). We previously demonstrated that a low expression of NIS mRNA levels, quantified by realtime PCR, identifies aggressive thyroid tumors (55). Unfortunately, we were not able to find any relationship between NIS protein expression and patients' outcome in the same cohort mentioned above. Once again, the Kaplan-Meier survival curve of these patients, displayed in figure 4, suggested that a longer follow-up and/or a larger cohort may prove NIS to be a useful immunohistochemical and perhaps even immunocytochemical prognostic marker, although our preliminary data were not statistically significant in terms of outcome prediction.

Other genes directly related to thyroid tumorigenesis have actively been investigated as potential prognostic markers. One of the most exciting is BRAF. In vitro and in vivo models have demonstrated that overexpression of activated BRAF induces malignant transformation and aggressive tumor behavior, further discussed in another article of this issue. BRAF and other RAF kinases are frequently activated by other thyroid oncogenes and are important mediators of their biological effects, including dedifferentiation and proliferation. Two large studies showed that BRAF mutation

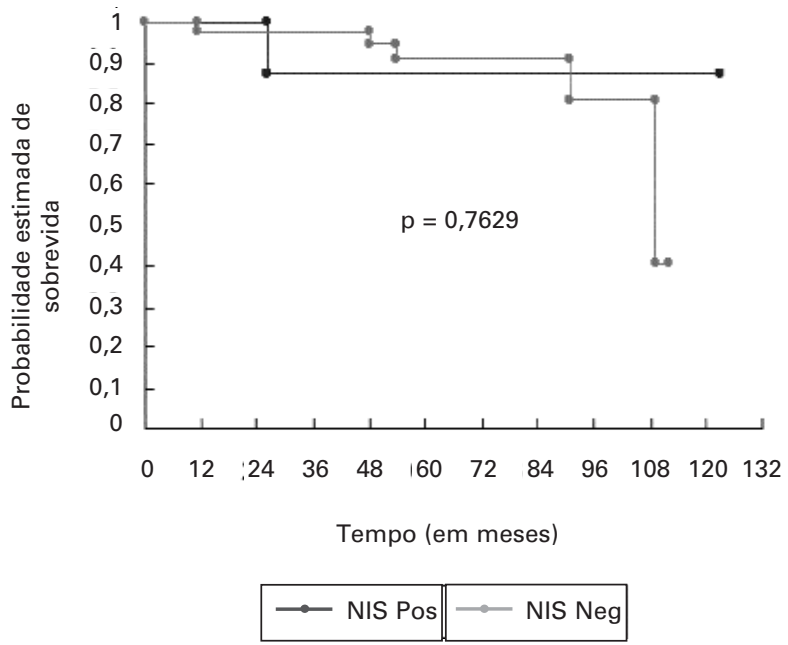

Figure 4. Kaplan-Meier survival curve (estimated probability of survival) of 50 differentiated thyroid cancer patients that were either immunohistochemically NIS positive or negative followed-up for 120 months. predicts a poorer clinical prognosis for papillary thyroid cancer $(56,57)$. However, a recent study from the Pisa group challenged these studies. A review of 61 papillary thyroid carcinoma patients with BRAF mutations, followed-up for 6 years, did not show evidence of any prognostic utility for BRAF (58).

In addition to the genes directly related to thyroid follicular cell differentiation, low-penetrance genes or rather polymorphisms in such genes could be of great significance to understand the tumorigenic processes of thyroid carcinomas.

\section{DETOXIFICATION SYSTEMS AND THYROID CARCINOMA SUSCEPTIBILITY}

As discussed, the thyroid cancer etiology is markedly uncertain. A wide variety of drugs, pesticides, goitrogenic xenobiotics and chemicals have been shown to increase the incidence of thyroid tumors in rodents (59-61). However, chemicals have seldom been associated with human thyroid cancer, in contrast to lung, bladder, and many other cancers. No increase in the human thyroid cancer risk has ever been consistently observed with any drug $(62,63)$. On the other hand, there is compelling evidence that environmental factors, besides ionizing radiation, influence cancer incidence. Thyroid cancer is the fastest growing type of cancer in the USA with a $6.3 \%$ increase during the period of 1997-2003 and we have data suggesting that in Brazil it is not different $(12,64)$. However, the rate of increase as well as the incidence of thyroid cancer varies in different geographic and ethnic group regions, including individuals exposed to welldefined factors, such as ionizing radiation (44-47,64-67). The question may be posed as to why some individuals are more susceptible to environmental aggressions? The biochemical basis for this susceptibility is related to genetic polymorphisms that normally occur in the general population regarding genes involved in the predisposition to a specific cancer, in the metabolic activation or detoxification of environmental genotoxins, as well as in controlling DNA repair or cellular damage (67-72).

Several polymorphic genes, encoding for enzymes involved in the biotransformation of carcinogens, have been studied as possible cancer risk modifiers. One of the most primitive defense mechanisms against environmental carcinogens is a supergene family of dimeric enzymes that are expressed in probably all life forms, the glutathione S-transferase (73). These enzymes catalyze the conjugation of glutathione to a variety of electrophiles, including arene oxides, inorganic arsenic, unsaturated carbonyls, organic halides and other substrates or oxida- 
tive stress products (74). We demonstrated that the inheritance of null forms of genes codifying some of these enzymes (75), as well as of polymorphic gene variants that produce less active forms of enzymes (76), increase the susceptibility to thyroid differentiated cancer. Other polymorphic gene systems of defense may be involved in thyroid cancer risk. Preliminary data from our group showed that $\mathrm{N}$-acetyl transferase 2 genes as well are involved in thyroid cancer risk (77).

Among the genes involved in cellular repair, p53 polymorphism is one of the most interesting. This polymorphism has been shown to have varying ethnic and geographical distribution, like most genetic human polymorphisms. It has been reported to be a potential genetic risk factor for many types of cancer, and we as well as others have demonstrated that it is also involved in thyroid cancer risk $(78,79)$.

Many other systems may possibly be involved in the complex interaction between human beings and environment that ultimately leads to cancer. A series of promising reports identifying polymorphisms in germline DNA have been published in an effort to delineate polygenic models of thyroid cancer susceptibility and prognosis (80-82). Such models are particularly interesting since they may help select individuals for specific chemopreventive interventions and determine which patients with nodules or with microcarcinomas are most likely to benefit from specific therapies. Unfortunately, these studies have produced inconsistent results mostly derived from small samples but also from population stratification secondary to ethnic diversity, heterogeneity of the therapeutic measures employed as well as consideration being limited to only one rather than combinations of polymorphisms. In addition, an important limitation in case-control studies is the fact that some population controls may have undetected thyroid lesions that could mislead the interpretation of the observed associations. Our studies have the advantage of using the Brazilian population, which presents a highly heterogeneous ethnic composition. Nonetheless, larger cohorts and metanalysis are needed. Hopefully, a panel of molecular markers will be able to identify early on life those at risk for thyroid cancer, hence helping define preventive strategies for these individuals in a near future.

\section{PREDICTORS OF THYROID OUTCOME}

The thyroid cancer patient needs to be reevaluated at each clinical appointment. As stated in the Guidelines also published in this issue of the ABEM, this evaluation outlines the patient's outcome and defines further strategies.

\section{Laboratory data}

Thyroid hormone suppression lessens disease progression in high-risk papillary thyroid carcinoma (83). Recent data indicate that thyroid hormone suppressive therapy that yields serum TSH levels in the subnormal range also improves overall survival of patients with stage II differentiated thyroid cancer, but no additional improvement is associated with further degrees of thyroid hormone suppression (84). These data reinforce our Guideline recommendations: more aggressive thyroid hormone suppressive therapy is warranted in high-risk patients, whereas less aggressive thyroid hormone suppressive therapy aimed to maintain TSH levels slightly below normal is indicated in low-risk patients. Moreover, TSH levels may be considered of prognostic significance, and add value to thyroglobulin $(\mathrm{Tg})$ measurement, which remains the most important predictor of outcome currently available for operated thyroid cancer patients (85-87).

\section{Images}

Nodule appearance on ultrasonography, together with ultrasound-guided fine-needle aspiration cytology, and neck exam during thyroid cancer follow-up are cornerstones of the current management of thyroid lesions. As more comprehensively discussed elsewhere in this issue of the ABE\&M, ultrasonography is superior to other imaging methods, such as magnetic resonance imaging or computed tomography scan, except in particular cases $(88,89)$.

More recently, ${ }^{18}$ F-FDG $\mathrm{PET} / \mathrm{CT}$ has emerged as a promising imaging modality to evaluate thyroid malignancies, as extensively discussed in another manuscript of this issue of the ABE\&M. PET and $\mathrm{PET} / \mathrm{CT}$ are highly sensitive for $\mathrm{Tg}$ and/or radioiodine negative-scan thyroids, primary, poorly differentiated or anaplastic tumors, and metastatic lesions (90). However, their role as predictors of thyroid tumor aggressiveness remains to be evaluated.

\section{Fractal dimension}

Cell structural and biochemical features change with increasing aggressiveness of a neoplasia. Morphometric and texture analyses of whole tissue sections or individual cells are simple, reproducible and inexpensive. Staining can be done on routine slides. Pathologists have proposed the fractal dimension of nuclear chromatin as a prognostic factor in some tumors, such as lymphoblastic leukemia (91), myelodysplastic syndromes (92) and laryngeal carcinoma (93). This is a promising method that may estimate patients' outcome early on a cytological fine-needle aspirate, since 
it has also been used for fine-needle aspirates from breast cytology (94). Recent data suggest that this technique may be applied to thyroid and possibly be useful in predicting aggressiveness (95).

\section{CONCLUSION}

Screening tools designed to identify individuals at risk for thyroid nodule cancer are of extreme necessity. Some clinical and epidemiologic features, among other factors, have proved to be important in the identification of individuals at risk. However, an appropriate management algorithm should balance sensitivity in detecting malignancy against the costs of an additional evaluation, which poses considerable costs to the patient and to society $(96,97)$. Likewise, the management of patients diagnosed with thyroid tumors demands the understanding of the factors that drive follicular cells towards a non-return path of dedifferentiation. New promising tools have been developed and hopefully we will soon be able to sort out aggressive cases from the vast majority of indolent thyroid cancers that, perhaps in a not so distant future, will be merely observed without invasive intervention.

\section{REFERENCES}

1. Yousem DM, Huang T, Loevner LA, Langlotz CP. Clinical and economic impact of incidental thyroid lesions found with CT and MR. AJNR 1997:18:1423-8.

2. Ezzat S, Sarti DA, Cain DR, Braunstein GD. Thyroid incidentalomas. Prevalence by palpation and ultrasonography. Arch Intern Med 1994;154:1838-40.

3. Davies L, Welch HG. Increasing incidence of thyroid cancer in the United States, 1973-2002. JAMA 2006:295:2164-7.

4. Harach HR, Franssila KO, Wasenius V. Occult papillary carcinoma of the thyroid. A "normal" finding in Finland. A systemic autopsy study. Cancer 1985;56:531-8.

5. Franssila KO, Harach HR. Occult papillary carcinoma of the thyroid in children and young adults: A systemic autopsy study in Finland. Cancer 1986:58:715-9.

6. Lang W, Borrusch H, Bauer L. Occult carcinomas of the thyroid: Evaluation of 1020 sequential autopsies. Am J Clin Pathol 1988:40:72-6.

7. Martinez-Tello FJ, Martinez-Cabruja R, Fernandez-Martin J, Lasso-Oria C, Ballestin-Carcavilla C. Occult carcinoma of the thyroid. A systematic autopsy study from Spain of two series performed with two different methods. Cancer 1993:71:4022-9.

8. Hefer TH, Joachims HZ, Hashinonai M, Bem-Arieh Y, Brown J. Highly aggressive behaviour of occult papillary thyroid carcinoma. J J Laryngol Otol 1995;109:1109-12.

9. Nogushi S, Yamashita H, Murakami N, Nakayama I, Toda M, Kawamoto $\mathrm{H}$. Small carcinoma of the thyroid. A long-term follow-up of 867 patients. Arch Surg 1996;131:187-91.

10. Fink A, Tomlinson G, Freeman JL, Rosen IB, Asa SL. Occult micropapillary carcinoma associated with benign follicular thyroid disease and unrelated thyroid neoplasms. Mod Pathol 1996;9:816-20.

11. Mitselou A, Vougiouklakis $T$, Peschos D, Dallas P, Agnantis NJ. Occult thyroid carcinoma. A study of 160 autopsy cases. The first report for the region of Epirus-Greece. Anticancer Res 2002:22:427-32.
12. Coeli CM, Brito AS, Barbosa FS, Ribeiro MG, Sieiro APAV, Vaisman M. Incidence and mortality from thyroid cancer in Brazil. Arq Bras Endocrinol Metab 2005;49:503-9.

13. de Matos PS, Ferreira AP, Ward LS. Prevalence of papillary microcarcinoma of the thyroid in Brazilian autopsy and surgical series. Endocr Pathol 2006;17:165-73.

14. Chan EK, Sepkovic DW, Yoo Bowne HJ, Yu GP, Schantz SP. A hormonal association between estrogen metabolism and proliferative thyroid disease. Otolaryngol Head Neck Surg 2006;134:893-900

15. Ward LS, Assumpção LVM. The impact of gender in differentiated thyroid cancer. Clin Endocrinol (Oxf) 2007;66(5):752; author reply 752-3.

16. Mazzaferri EL, Kloos RT. Current approaches to primary therapy for papillary and follicular thyroid cancer. J Clin Endocrinol Metab 2001;86:1447-63.

17. Vivacqua A, Bonofiglio D, Albanito L, Madeo A, Rago V, Carpino $A$, et al. 17 $\beta$-estradiol, genistein, and 4-hydroxytamoxifen induce the proliferation of thyroid cancer cells through the $G$ protein-coupled receptor GPR30. Mol Pharmacol 2006;70:1414-23.

18. NCCN and AJCC/IUCC thyroid carcinoma practice guidelines. Available at: <http://www.nccn.org/professionals/physician_gls $>$. Accessed in February 2007.

19. Wada N, Nakayama H, Suganuma N, Masudo Y, Rino Y, Masuda $\mathrm{M}$, et al. Prognostic value of the sixth edition AJCC/UICC TNM classification for differentiated thyroid carcinoma with extrathyroid extension. J Clin Endocrinol Metab 2007;92:215-8.

20. Shaha AR. TNM classification of thyroid carcinoma. World $\mathbf{J}$ Surg 2007;31(5):879-87.

21. Ward LS, Facuri FO, Araújo PPC, Tincani AJ, Assumpção LVM. Commonly used prognostic scoring systems are not adequate to predict the outcome of papillary microcarcinomas of the thyroid. J Sur Onco 2007; accepted for publication.

22. Ward LS, Assumpção LV. Thyroid cancer: prognostic factors and treatment. Arq Bras Endocrinol Metab 2004;48:126-36.

23. Lundgren $\mathrm{Cl}$. Are possible risk factors for differentiated thyroid cancer of prognostic importance? Thyroid 2006;16:65966.

24. Russell JP, Engiles JB, Rothstein JL. Proinflammatory mediators and genetic background in oncogene mediated tumor progression. J Immunol 2004;172:4059-67.

25. Souza SL, Assumpção LV, Ward LS. Impact of previous thyroid autoimmune diseases on prognosis of patients with well-differentiated thyroid cancer. Thyroid 2003;13:491-5.

26. Mack WJ, Preston-Martin S, Dal Maso L, Galanti R, Xiang M, Franceschi $\mathrm{S}$, et al. A pooled analysis of case-control studies of thyroid cancer: cigarette smoking and consumption of alcohol, coffee, and tea. Cancer Causes Control 2003:14:773-85.

27. Navarro Silvera SA, Miller AB, Rohan TE. Risk factors for thyroid cancer: a prospective cohort study. Int $J$ Cancer 2005;116:433-8.

28. Bufalo NE, Leite JL, Guilhen AC, Morari EC, Granja F, Assumpção LV, et al. Smoking and susceptibility to thyroid cancer: an inverse association with CYP1A1 allelic variants. Endocr Relat Cancer 2006:13:1185-93.

29. Barbaro D, Simi U, Meucci G, Lapi P, Orsini P, Pasquini C. Thyroid papillary cancers: microcarcinoma and carcinoma, incidental cancers and non-incidental cancers - are they different diseases? Clin Endocrinol (Oxf) 2005;63:577-81.

30. Hefer TH, Joachims HZ, Hashinonai M, Bem-Arieh Y, Brown J. Highly aggressive behaviour of occult papillary thyroid carcinoma. J Laryngol Otol 1995;109:1109-12.

31. Livolsi VA. Highly aggressive behaviour of occult papillary thyroid carcinoma. J Laryngol Otol 1996;110:710.

32. Farid NR, Shi Y, Zou M. Molecular basis of thyroid cancer. Endocr Rev 1994;15:202-32.

33. Memon A, Berrington De Gonzalez A, Luqmani Y, Suresh A. Family history of benign thyroid disease and cancer and risk of thyroid cancer. Eur J Cancer 2004:40:754-60.

34. Schlumberger MJ. Papillary and follicular thyroid carcinoma. Baillieres Best Pract Res Clin Endocrinol Metab 2000:14:601-13. 
35. Kazakov VS, Demidchik EP, Astakhova LN. Thyroid cancer after Chernobyl. Nature 1992;359:421.

36. Lemoine NR, Mayall ES, Wyllie FS, Williams ED, Goyns M, Stringer B, et al. High frequency of ras oncogene activation in all stages of human thyroid tumorigenesis. Oncogene 1989;4:159-64.

37. Grieco M, Santoro M, Berlingieri MT, Melillo RM, Donghi R, Bongarzone I, et al. PTC is a novel rearranged form of the ret proto-oncogene and is frequently detected in vivo in human thyroid papillary carcinomas. Cell 1990;60:557-63.

38. Kimura ET, Nikiforova MN, Zhu Z, Knauf JA, Nikiforov YE, Fagin JA. High prevalence of BRAF mutations in thyroid cancer: genetic evidence for constitutive activation of the RET/PTC-RAS-BRAF signaling pathway in papillary thyroid carcinoma. Cancer Res 2003;63:1454-7.

39. Kroll TG, Sarraf P, Pecciarini L, Chen CJ, Mueller E, Spiegelman BM, et al. PAX8-PPAR 1 fusion oncogene in human thyroid carcinoma. Science 2000;289:1357-60.

40. Fagin JA, Matsuo K, Karmakar A, Chen DL, Tang SH, Koeffler HP. High prevalence of mutations of the p53 gene in poorly differentiated human thyroid carcinomas. J Clin Invest 1993; $91: 179-84$

41. Ward LS, Brenta G, Medvedovic M, Fagin JA. Studies of allelic loss in thyroid tumors reveal major differences in chromosomal instability between papillary and follicular carcinomas. J Clin Endocrinol Metab 1998:83:525-30.

42. Finn S, Smyth P, O'Regan E, Cahill S, Toner M, Timon C, et al. Low-level genomic instability is a feature of papillary thyroid carcinoma: an array comparative genomic hybridization study of laser capture microdissected papillary thyroid carcinoma tumors and clonal cell lines. Arch Pathol Lab Med 2007:131:65-73.

43. Demidchik EP, Mrochek A, Demidchik Yu, et al. Thyroid cancer promoted by radiation in young people of Belarus. In: Thomas G, Karaoglou A, Williams ED, (eds). Radiation and Thyroid Cancer. Singapore: World Scientific, 1999.

44. Jacob P, Bogdanova TI, Buglova E, Chepurniy M, Demidchik $Y$, Gavrilin $Y$, et al. Thyroid cancer among Ukrainians and Belarusians who were children or adolescents at the time of the Chernobyl accident. J Radiol Prot 2006;26:51-67.

45. Imaizumi M, Usa T, Tominaga T, Neriishi K, Akahoshi M, Nakashima E, et al. Radiation dose-response relationships for thyroid nodules and autoimmune thyroid diseases in Hiroshima and Nagasaki atomic bomb survivors $55-58$ years after radiation exposure. JAMA 2006;295:1011-22.

46. Ron E, Lubin JH, Shore RE, Mabuchi K, Modan B, Pottern LM, et al. Thyroid cancer after exposure to external radiation, a pooled analysis of 7 studies. Radiat Res 1995;141:259-77.

47. Williams ED. Chernobyl and thyroid cancer. J Surg Oncol 2006:94:670-7.

48. Feldt-Rasmussen U. lodine and cancer. Thyroid 2001;11:483-6.

49. Zafon C, Obiols G, Castellvi J, Tallada N, Baena JA, Simo R, et al. Clinical significance of RET/PTC and p53 protein expression in sporadic papillary thyroid carcinoma. Histopathology 2007; $50: 225-31$.

50. Jossart GH, Epstein HD Shaver JK, Weier HU, Greulich KM, Tezelman S, et al. Immunocytochemical detection of p53 in human thyroid carcinomas is associated with mutation and immortalization of cell lines. J Clin Endocrinol Metab 1996:81:3498-504.

51. Ward LS, Fagin JA. Molecular genetics of thyroid cancer: evidence that inactivation of tumor suppressor genes occurs at late stages of tumor progression. In: Handwerger S. Molecular and Cellular Pediatric Endocrinology. Totowa: Humana Press Inc, 1998.

52. Wreesmann VB, Sieczka EM, Socci ND, Hezel M, Belbin TJ Childs G, et al. Genome-wide profiling of papillary thyroid cancer identifies MUC1 as an independent prognostic marker. Cancer Res 2004:64:3780-9.

53. Patel KN, Maghami E, Wreesmann VB, Shaha AR, Shah JP, Ghossein $\mathrm{R}$, et al. MUC1 plays a role in tumor maintenance in aggressive thyroid carcinomas. Surgery 2005;138:994-1001.
54. Gilliland FD, Hunt WC, Morris DM, Key CR. Prognostic factors for thyroid carcinoma. A population-based study of 15,698 cases from the Surveillance, Epidemiology and End Results (SEER) program 1973-1991. Cancer 1997;79:564-73.

55. Ward LS, Santarosa PL, Granja F, Assumpção LV, Savoldi M, Goldman GH. Low expression of sodium iodide symporter identifies aggressive thyroid tumors. Cancer Let 2003; 200:85-91.

56. Xing $M$, Westra WH, Tufano RP, Cohen $Y$, Rosenbaum E, Rhoden $\mathrm{KJ}$, et al. BRAF mutation predicts a poorer clinical prognosis for papillary thyroid cancer. J Clin Endocrinol Metab 2005; 90 :6373-9.

57. Kim TY, Kim WB, Rhee YS, Song JY, Kim JM, Gong G, et al. The BRAF mutation is useful for prediction of clinical recurrence in low-risk patients with conventional papillary thyroid carcinoma. Clin Endocrinol 2006:65:364-8.

58. Fugazzola L, Puxeddu E, Avenia N, Romei C, Cirello V, Cavaliere $A$, et al. Correlation between B-RAFV600E mutation and clinico-pathologic parameters in papillary thyroid carcinoma: data from a multicentric Italian study and review of the literature. Endocr Relat Cancer 2006;13:455-64.

59. Capen CC. Mechanistic data and risk assessment of selected toxic end points of the thyroid gland. Toxicol Pathol 1997; 25:39-48.

60. Hard GC. Recent developments in the investigation of thyroid regulation and thyroid carcinogenesis. Environ Health Perspect 1998;106:427-36.

61. Hurley PM. Mode of carcinogenic action of pesticides inducing thyroid follicular cell tumors in rodents. Environ Health Perspect 1998:106:437-45.

62. Schlumberger MJ. Papillary and follicular thyroid carcinoma. Baillieres Best Pract Res Clin Endocrinol Metab 2000:14:601-13.

63. Hallquist A, Hardell L, Degerman A, Boquist, L. Thyroid cancer: reproductive factors, previous diseases, drug intake, family history and diet. A case-control study. Eur J Cancer Prev 1994:3:481-8.

64. Ries LAG, Harkins D, Krapcho M, Mariotto A, Miller BA, Feuer EJ, et al. (eds). SEER Cancer Statistics Review, 1975-2003. National Cancer Institute, 2006. Available at: <http://www. nccn.org/professionals/>. Accessed in February 2007.

65. Ron E, Kleinerman RA, Boice Jr JD, LiVolsi VA, Flannery JT, Fraumeni Jr JF. A population-based case-control study of thyroid cancer. J Natl Cancer Inst 1987;79:1-12.

66. Haselkorn T, Stewart SL, Horn-Ross PL. Why are thyroid cancer rates so high in Southeast Asian women living in the United States? The Bay Area thyroid cancer study. Cancer Epidemiol Biomark Prev 2003;12:144-50.

67. Mack WJ, Preston-Martin S, Bernstein L, Qian D. Lifestyle and other risk factors for thyroid cancer in Los Angeles County females. Ann Epidemiol 2002;12:395-401.

68. Vineis P. Cancer as an evolutionary process at the cell level: an epidemiological perspective. Carcinogenesis 2003:24:1-6.

69. Lichtenstein P, Holm NV, Verkasalo PK, Iliadou A, Kaprio J, Koskenvuo $\mathrm{M}$, et al. Environmental and heritable factors in the causation of cancer. NEJM 2000;343:78-85.

70. Vineis $\mathrm{P}$, Matullo G, Manuguerra M. An evolutionary paradigm for carcinogenesis? J Epidemiol Community Health 2001;57;89-95.

71. Autrup H. Genetic polymorphisms in human xenobiotic metabolizing enzymes as susceptibility factors in toxic response. Mutat Res 2000;464:65-76.

72. Clapper ML. Genetic polymorphism and cancer risk. Curr Oncol Rep 2000;2:251-6.

73. Mannervik B. The isozymes of glutathione S-transferase. Adv Enzymol 1985; 57:357-417.

74. Strange RC, Fryer AA. The glutathione S-transferases: influence of polymorphism on cancer susceptibility. IARC Sci Publ 1999; 148:231-49.

75. Morari EC, Leite JL, Granja F, Assumpção LV, Ward LS. The null genotype of glutathione s-transferase M1 and T1 locus increases the risk for thyroid cancer. Cancer Epidemiol Biomark Prev 2002;11:1485-8. 
76. Granja F, Morari J, Morari EC, Correa LA, Assumpção LV, Ward LS. GST profiling may be useful in the screening for thyroid nodule malignancy. Cancer Lett 2004;209:129-37.

77. Trindade ACG, Granja F, Kitagaki Jr HA, Assumpção LVM, Ward LS. Influência do gene N-Acetil Transferase 2 (NAT2) na susceptibilidade ao câncer da tiróide na população brasileira. Arq Bras Endocrinol Metab 2006;50(3):S238.

78. Granja F, Morari J, Morari EC, Correa LA, Assumpção LV, Ward LS. Proline homozygosity in codon 72 of p53 is a factor of susceptibility for thyroid cancer. Cancer Lett 2004; 210:151-7.

79. Rogounovitch TI, Saenko VA, Ashizawa K, Sedliarou IA Namba H, Abrosimov AY, et al. TP53 codon 72 polymorphism in radiation-associated human papillary thyroid cancer. Oncol Rep 2006; 15:949-56.

80. Bonora E, Evangelisti C, Bonichon F, Tallini G, Romeo G. Novel germline variants identified in the inner mitochondrial membrane transporter TIMM44 and their role in predisposition to oncocytic thyroid carcinomas. Br J Cancer 2006:95:1529-36.

81. Maximo V, Botelho T, Capela J, Soares P, Lima J, Taveira A, et al. Somatic and germline mutation in GRIM-19, a dual function gene involved in mitochondrial metabolism and cell death, is linked to mitochondrion-rich (Hürthle cell) tumours of the thyroid. Br J Cancer 2005;92:1892-8.

82. Baida A, Farrington SM, Galofre $P$, Marcos $R$, Velazquez A. Thyroid cancer susceptibility and THRA1 and BAT-40 repeats polymorphisms. Cancer Epidemiol Biomark Prev 2005; 14:638-42.

83. Cooper DS, Specker B, Ho M, Sperling M, Ladenson PW, Ross DS, et al. Thyrotropin suppression and disease progression in patients with differentiated thyroid cancer: results from the National Thyroid Cancer Treatment Cooperative Registry. Thyroid 1998;8:737-44

84. Jonklaas J, Sarlis NJ, Litofsky D, Ain KB, Bigos ST, Brierley JD, et al. Outcomes of patients with differentiated thyroid carcinoma following initial therapy. Thyroid 2006;16:1229-42.

85. Verkooijen RB, Rietbergen D, Smit JW, Romijn JA, Stokkel MP. A new functional parameter measured at the time of ablation that can be used to predict differentiated thyroid cancer recurrence during follow-up. Eur $J$ Endocrinol 2007; 156:41-7.

86. Eustatia-Rutten CF, Smit JW, Romijn JA, van der Kleij-Corssmit EP, Pereira AM, Stokkel MP, et al. Diagnostic value of serum thyroglobulin measurements in the follow-up of differentiated thyroid carcinoma, a structured meta-analysis. Clin Endocrinol 2004:61:61-74.

87. Heemstra KA, Liu YY, Stokkel M, Kievit J, Corssmit E, Pereira $A M$, et al. Serum thyroglobulin concentrations predict disease-free remission and death in differentiated thyroid carcinoma. Clin Endocrinol 2007;66:58-64.
88. King AD, Ahuja AT, To EW, Tse GM, Metreweli C. Staging papillary carcinoma of the thyroid: magnetic resonance imaging vs. ultrasound of the neck. Clin Radiol 2000;55:222-6.

89. Shetty SK, Maher MM, Hahn PF, Halpern EF, Aquino SL. Significance of incidental thyroid lesions detected on CT: correlation among CT, sonography, and pathology. AJR Am J Roentgenol 2006;187:1349-56.

90. Quon A, Fischbein NJ, McDougall IR, Le QT, Loo BW Jr, Pinto $\mathrm{H}$, et al. Clinical role of $18 \mathrm{~F}-\mathrm{FDG}$ PET/CT in the management of squamous cell carcinoma of the head and neck and thyroid carcinoma. J Nucl Med 2007;48:58S-67S.

91. Adam RL, Silva RC, Pereira FG, Leite NJ, Lorand-Metze I, Metze K. The fractal dimension of nuclear chromatin as a prognostic factor in acute precursor B lymphoblastic leukemia. Cell Oncol 2006;28:55-9.

92. Lorand-Metze I, Ribeiro E, Lima CS, Batista LS, Metze K. Detection of hematopoietic maturation abnormalities by flow cytometry in myelodysplastic syndromes and its utility for the differential diagnosis with non-clonal disorders. Leuk Res 2007;31:147-55.

93. Delides A, Panayiotides I, Alegakis A, Kyroudi A, Banis C, Pavlaki $A$, et al. Fractal dimension as a prognostic factor for laryngeal carcinoma. Anticancer Res 2005;25:2141-4.

94. Einstein AJ, Wu HS, Sanchez M, Gil J. Fractal characterization of chromatin appearance for diagnosis in breast cytology. $\mathbf{J}$ Pathol 1998:185:366-81.

95. Ferreira RC, de Matos PS, Adam RL, Leite NJ, Metze K. Application of the Minkowski-Bouligand fractal dimension for the differential diagnosis of thyroid follicular neoplasias. Cell Oncol 2006;28:331-3.

96. Florentine BD, Staymates B, Rabadi M, Sarda N, Barstis J, Black A; Cancer Committee of the Henry Mayo Newhall Memorial Hospital. Cost savings associated with the use of fine-needle aspiration biopsy (FNAB) for the diagnosis of palpable masses in a community hospital-based FNAB clinic. Cancer 2006;107:2270-81.

97. Khalid AN, Hollenbeak CS, Quraishi SA, Fan CY, Stack BC Jr. The cost-effectiveness of iodine 131 scintigraphy, ultrasonography, and fine-needle aspiration biopsy in the initial diagnosis of solitary thyroid nodules. Arch Otolaryngol Head Neck Surg 2006;132:244-50.

Address for correspondence:

Laura S. Ward

aboratory of Cancer Molecular Genetics

$\mathrm{FCM}$ - Unicamp

Rua Tessália Vieira de Camargo 161

13081-970 Campinas, SP

Fax: (19) 3521-7878

E-mail: ward@unicamp.br 